\title{
Stoking residue from extraction of cassava starch without the use of storage technologies
}

\author{
Estocagem do resíduo da extração de amido da mandioca sem utilização de tecnologias de \\ armazenamento
}

\author{
Cleovani Rossi Javorski ${ }^{\mathrm{I}}$ Maximiliane Alavarse Zambom $^{\mathrm{I}^{*}}$ Magali Soares dos Santos Pozza \\ Tatiane Fernandes ${ }^{\text {III }}$ Deise Dalazen Castagnara ${ }^{\text {IV }}$ Simoni Paladini ${ }^{I}$ Rodrigo Cesar dos Reis Tinini ${ }^{I}$ \\ Marcela Abbado Neres ${ }^{\mathrm{I}}$
}

\begin{abstract}
The purpose of this paper was to study the storage of the residue from the extraction of cassava starch without the use of storage technologies, through chemical evaluation, $\mathrm{pH}$ values, temperature, development of microorganisms and mycotoxins. A randomized block design was used with eight treatments (different storage periods: 0, 3, 6, 9, 12, 15, 18 and 21 days) and five replications. There was a significant difference for DM content, as a function of days in storage. The chemical composition of the residue from the extraction of cassava starch did not changed throughout the storage period. A negative linear effect was obtained for the $\mathrm{pH}$ values, which decreased with days in storage. There was significance of the storage period only for the fungus and yeast population, which increased up to 17 days of storage, with subsequent reduction. Mycotoxins were detected in the residue from the extraction of cassava starch. Despite it did not showed changes in the chemical composition the storage of residue from the extraction of cassava starch for 21 days proved to be an inefficient preservation process, due to the development of molds and mycotoxins.
\end{abstract}

Key words: conservation, Manihot esculenta, wet material, mycotoxins, microorganisms

RESUMO

Objetivou-se estudar o armazenamento do resíduo da extração de amido da mandioca, sem a utilização de tecnologias, por meio da avaliação química, valores de $\mathrm{pH}$, temperatura, desenvolvimento de microrganismos e micotoxinas. $O$ delineamento utilizado foi em blocos casualizados com oito tratamentos (diferentes dias de estocagem: 0, 3, 6, 9, 12, 15, 18 e 21) e cinco repetições. Houve diferença significativa para o teor de MS em função dos dias de estocagem. Obteve-se efeito linear negativo para os valores de $\mathrm{pH}$, os quais decresceram com os dias de armazenamento. Houve significância do período de estocagem apenas sobre a população de fungos e leveduras, que se elevou até os 17 dias de estocagem, com posterior redução, micotoxinas foram detectadas no resíduo da extração do amido da mandioca. Apesar de não apresentar alterações na composição química, a estocagem do resíduo da extração do amido da mandioca por 21 dias demonstrou ser um processo de conservação ineficiente, devido ao desenvolvimento de fungos e presença de micotoxinas.

Palavras-chave: conservação, Manihot esculenta, material úmido, micotoxinas, microorganismos.

\section{INTRODUCTION}

In the ruminant, it is possible to use agroindustrial residues in feed (GONÇALVES et al., 2014), due to the ability of rumen fermentation that these animals have. This is an effective strategy (SOUZA et al., 2012), adopted by many producers to seek reduction in production costs, since, feed costs can represent up to $70 \%$ of production costs (JOBIM et al., 2007).

Many residues can be used, which has highlighted the residue from the extraction of cassava starch (RECS). Because it presents considerable nutritional quality for ruminant (ABRAHÃO et al., 2006) as well as high availability in nearby regions to the cassava processing industries (ZAMBOM et al., 2012).

ICentro de Ciências Agrárias, Universidade Estadual do Oeste do Paraná (UNIOESTE), 85605-010, Marechal Cândido Rondon, PR, Brasil. E-mail: mazambom@hotmail.com. *Corresponding author.

IIDepartamento de Zootecnia, Universidade Estadual de Maringá (UEM), Maringá, PR, Brasil.

IIIDepartamento de Zootecnia, Universidade Federal de Lavras (UFLA), Lavras, MG, Brasil.

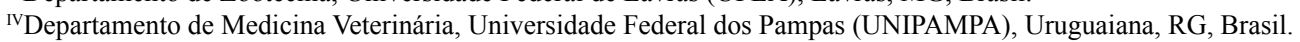


Approximately $928.6 \mathrm{~kg}$ of residue are produced with $75 \%$ humidity, for each ton of processed cassava root (CEREDA, 2000), generating an amount of approximately 1,928.52ton of residue annually in Brazil, considering production data from approximately 519.20ton in 2011 (SEBRAE, 2012).

One of the obstacles encountered in the use of this residue is the high humidity level of this material, a negative factor for the storage of the same (ABRAHÃO et al., 2006). Drying of this residue in the manufacturing industry economically prevents their use for feeding ruminants (FERNANDES, 2014). It's necessary to evaluate the storage process to secure that food maintains its quality, which is essential for maintaining animal production efficiency (JOBIM et al., 2007).

In this context, the purpose of the present study was to evaluate the chemical composition, the microbiological profile and the occurrence of mycotoxins in residue from the extraction of cassava starch stored under aerobic conditions for 21 days.

\section{MATERIAL AND METHODS}

In the period from June to October 2011, it was obtained at five different times loads of 1 ton of residue from the extraction of cassava starch (RECS) at industry in Marechal Cândido Rondon-PR. The Storage Assessment was proceeded after the material acquisition for a period of 21 days. During this period, and the residue was placed in concrete floors and black plastic was used for protection against climatic weather, simulating the real condition that occurs in the properties in the west of Paraná. It was adopted a randomized block design, to isolate the effect of the different times of acquisition and treatments consisted in different days of evaluation $(0,3,6,9,12,15,18$ and 21) after obtaining the residue.

To evaluate the quality of the stored material, on days $0,3,6,9,12,15,18$ and 21 the temperature measurement was carried out at five different points of the RECS, with the aid of a digital thermometer skewer, followed by sampling, to form a composite sample for each evaluation period of each load.

Immediately after sampling, the material was refrigerated and sent to the Laboratory for determination of the $\mathrm{pH}$ values by the CHERNEY \& CHERNEY methodology (2003). A microbiological growth analyses were determined by means of culture techniques according to SILVA et al. (1997), with the following culture media being used: (1) Potato Dextrose Agar, for the count of filamentous fungi, keeping the plates at ambient temperature for 5 to 7 days; (2) Plate Count Agar, total bacteria count, remaining in incubation at $35^{\circ} \mathrm{C}$ for 72 hours and (3) Reinforced Clostridial Agar, for the count of clostridial, remaining in anaerobic incubation using jars with the Gas-pak system at $35^{\circ} \mathrm{C}$ for 72 hours.

Because of the heterogeneity of the material assessed for inoculum preparation it was used $50 \mathrm{~g}$ sample of residue from the extraction of cassava starch to $450 \mathrm{~mL}$ of sterile distilled water, with subsequent homogenization by means of a magnetic stirrer. As of this solution, dilutions were made ranging from $10^{-1}$ to $10^{-7}$, using test tubes containing sterile distilled water. After the dilutions, seeding was performed on the plates using $0.1 \mathrm{~mL}$ of solution per plate for determination of filamentous fungi and $1 \mathrm{~mL}$ for the other microorganisms. The plates were prepared in triplicate for each dilution and culture medium.

After the incubation period, the colonies were counted using a Quebec colony counter, with the plates that presented from 30 to $300 \mathrm{CFU}$ (Colony Forming Units) per Petri plate being considered to counting. For each experimental unit, the simple average of the triplicate of the plates was made and the results were expressed in Log.

A sub sample of the RECS was subjected to pre-drying in a forced air circ REC Sulation laboratory oven at $55^{\circ} \mathrm{C}$ for $72 \mathrm{~h}$. The dehydrated samples were ground in a Wiley knife mill containing a sieve with 30 meshes. It was determined the contents of dry matter $(\mathrm{DM})$, mineral matter (MM), crude protein $(\mathrm{CP})$ and ethereal extract (EE) according to the methodology described in AOAC (1990). Determination of neutral detergent fiber (NDF), acid detergent fiber (ADF), cellulose and lignin was conducted according to VAN SOEST et al. (1991). Organic matter (OM) was estimated by the difference between the total of DM and the MM content.

The occurrence of mycotoxins was studied in the samples in reference to days 0 and 21 of the storage period. For this purpose, the procedures recommended by the manufacturer of immunoaffinity columns (Aflatest and zeatest, Vicam ${ }^{\circledR}$, Watertown, MA, EUA) were followed. It was weighed a $25 \mathrm{~g}$ of the sample and the extraction of zearalenone and aflatoxin was made by means of the addition of $5 \mathrm{~g}$ of $\mathrm{NaCl}$ and $125 \mathrm{~mL}$ of solution $80 \%$ methanol (methyl alcohol). This mixture was then beat in a mixer and filtered in qualitative filter paper. To carry out the analyses, $20 \mathrm{~mL}$ of the extract was diluted with $20 \mathrm{~mL}$ of PBS buffer solution and filtered in a $1 \mu \mathrm{m}$ microfiber filter. After, it was used a immunoaffinity 
column of a zearalatest and aflatest for extraction, and added a revealing solution. Reading was made on the fluorometer $\left(\mathrm{VINCAN}^{\circledR}\right)$ previously calibrated for reading, with range 0 to $300 \mathrm{ppm}$ analysis and detection limit of $0.10 \mathrm{ppm}$, for zearalnone, and with range 0 to $300 \mathrm{ppb}$ analysis and detection limit of $2.00 \mathrm{ppb}$ for aflatoxin.

The data obtained was subjected to analyses of variance and were studied by means of regression analysis to the $5 \%$ level of probability. For the data obtained in the mycotoxin analyses, the analysis of variance was carried out, and was subjected to the Tukey test.

\section{RESULTS AND DISCUSSION}

The dry matter content of the RECS underwent trough significant changes during the storage period in such a way that the values observed fit the quadratic regression (Table 1). The increase in the dry matter content was observed up to 14 days of storage, with subsequent reduction (Figure 1).

The loss of effluents was observed throughout the storage period, explaining the increase in the dry matter content. Reduction in dry matter content after the 14 days of storage is due to the occurrence of rains that affected the stored RECS, raising its moisture content. The RECS exhibit moisture content from about $87 \%$ with storage, the material loses, water content (moisture) through effluent leaching (GONÇALVES et al., 2014).

Upon storing a feed, it is necessary to minimize changes that may be caused by the environment, as for example, poor seal may result in contamination in the material and alterations caused by climate, such as the occurrence of strong rains, which may change the storage conditions of the material.

The contents of organic matter (OM), mineral matter $(\mathrm{MM})$, crude protein $(\mathrm{CP})$, ethereal extract (EE), neutral detergent fiber (NDF), acid detergent fiber (ADF), lignin and cellulose of the residue from the extraction of cassava starch did not had changes throughout the storage period (Table 1). According to RAMALHO (2006), residue from the extraction of cassava starch may show variations in its chemical composition depending on some factors inherent to the manioc itself, and also on the processing adopted at the manufacture. A result similar to this study was observed by ABRAHÃO et al. (2006), for their part, working with cassava byproduct, found mean values of $1.92 \%$ of $\mathrm{CP}, 0.29 \%$ of EE, $30.50 \%$ of NDF and $22.66 \%$ of ADF. It is possible that it have not been detected variation in crude protein and ether extract, due to low levels of these constituents in the material.

According to VAN SOEST (1994), lignin is a fraction that remains unchanged throughout the fermentation process. Although the present study did not use the fermentation or ensiling as a storage technique, due to the inherent characteristics of the material, there was a formation of a dense surface layer, preventing contact of air with the material in order to characterize a possible fermentation within the material, which may explain the lack of occurrence of changes in its values throughout the storage period.

In the present study no reduction was observed in the cellulose, probably due to inactivity of the cellulase, due to the industrial processing of cassava. According to VAN SOEST et al. (1994) during the storage there is no changes in the cellulose and lignin contents from forage.

Table 1 - Changes in the quimical composition of the residue from the extraction of cassava starch over the 21 days of storage.

\begin{tabular}{|c|c|c|c|c|c|c|c|c|c|c|}
\hline \multirow{2}{*}{ Quimical composition } & \multicolumn{8}{|c|}{ 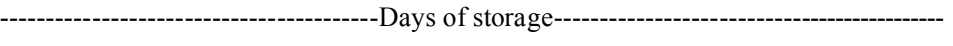 } & \multirow{2}{*}{$\mathrm{P}$} & \multirow{2}{*}{$\mathrm{CV}$} \\
\hline & 0 & 3 & 6 & 9 & 12 & 15 & 18 & 21 & & \\
\hline $\mathrm{OM}\left(\mathrm{g} \mathrm{kg}^{-1}\right)$ & 978.6 & 977.2 & 978.1 & 979.5 & 978.4 & 978.2 & 978.0 & 979.9 & 0.9191 & 0.33 \\
\hline $\mathrm{MM}\left(\mathrm{g} \mathrm{kg}^{-1}\right)$ & 19.8 & 20.3 & 20.5 & 19.2 & 20.1 & 20.4 & 19.0 & 19.1 & 0.5102 & 7.19 \\
\hline $\mathrm{CP}\left(\mathrm{g} \mathrm{kg}^{-1}\right)$ & 18.5 & 18.6 & 17.2 & 18.3 & 15.4 & 19.5 & 16.0 & 18.9 & 0.8682 & 27.50 \\
\hline $\mathrm{EE}\left(\mathrm{g} \mathrm{kg}^{-1}\right)$ & 15.3 & 17.1 & 13.9 & 13.8 & 16.0 & 16.2 & 13.5 & 17.1 & 0.4886 & 22.10 \\
\hline $\mathrm{NDF}\left(\mathrm{g} \mathrm{kg}^{-1}\right)$ & 364.4 & 329.8 & 334.5 & 338.5 & 355.1 & 356.9 & 354.8 & 356.2 & 0.9714 & 16.44 \\
\hline $\operatorname{ADF}\left(\mathrm{g} \mathrm{kg}^{-1}\right)$ & 325.9 & 374.2 & 331.1 & 380.8 & 336.2 & 386.7 & 370.6 & 376.2 & 0.9750 & 32.04 \\
\hline $\operatorname{Lignin}\left(\mathrm{g} \mathrm{kg}^{-1}\right)$ & 124.7 & 128.4 & 128.9 & 116.5 & 122.6 & 120.1 & 131.8 & 120.6 & 0.8683 & 14.03 \\
\hline Cellulose $\left(\mathrm{g} \mathrm{kg}^{-1}\right)$ & 213.4 & 194.5 & 187.7 & 201.5 & 210.6 & 201.1 & 185.7 & 191.3 & 0.5182 & 12.14 \\
\hline
\end{tabular}

OM: organic matter; MM: mineral matter; $\mathrm{CP}$ : crude protein; EE: ethereal extract; NDF: neutral detergent fiber; ADF: acid detergent fiber. $\mathrm{P}$ : level of significance; $\mathrm{NS}=\mathrm{P}>0.05 ; \mathrm{CV}(\%)$ : coefficient of variation. 


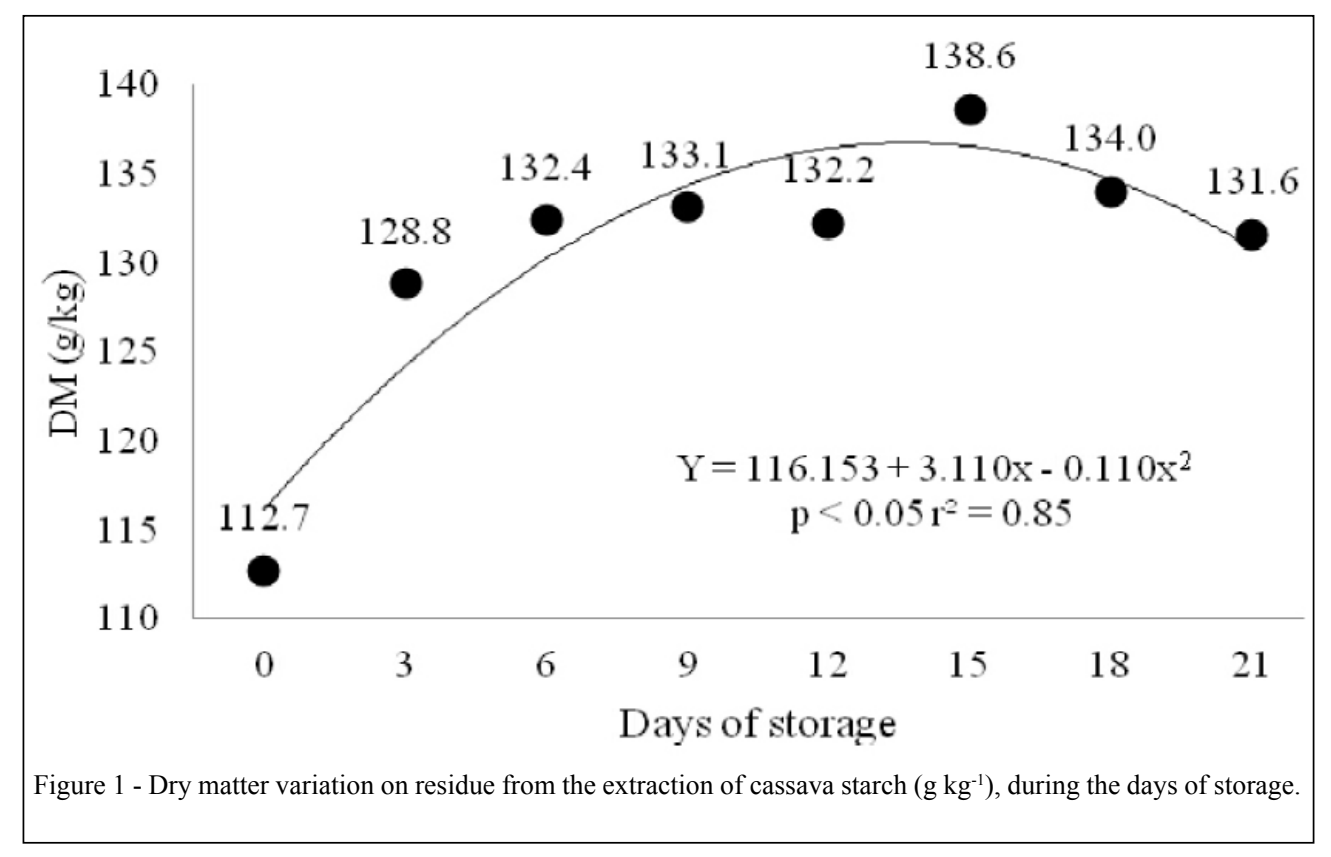

There was a linear reduction in the $\mathrm{pH}$ of residue from the extraction of cassava starch throughout the storage period, with a reduction of $0.080 \mathrm{pH}$ units every day of the storage period (Figure 2). According to MCDONALD (1991), high temperature and high $\mathrm{pH}$ values, without rapid reduction, promote the growth of undesirable microorganisms such as the clostridia, which may promote the degradation of organic compounds, reducing protein contents.

The $\mathrm{pH}$ values may favor or inhibit the development of microorganisms. The values observed in this study, which were from 5.1 (day 0) to 3.2 (day 21), despite the values observed being low, there was occurrence $t$ of some microorganisms (Table 2). According to JAY (2005), most microorganisms have their development in $\mathrm{pH}$ in the range from 6.6 to 7.5, but some microorganisms, like fungi and yeasts, can developed in lower $\mathrm{pH}$ levels.

Similar to that observed in this study, the reduction in the $\mathrm{pH}$ values was observed by SOUZA et al. (2012), evaluating the preservation of the brewery wet residue in aerobic and anaerobic conditions, presenting $\mathrm{pH}$ values of 6.03 at the time of acquisition of the material, and values of 3.69 at 21 days of storage. The author cites that despite the reduction in $\mathrm{pH}$ values, the temperature remained high, especially in the treatment where the residue was held in an aerobic environment, suggesting that the material may lead to the development of undesirable microorganisms.
In this experiment in which there was reduction in $\mathrm{pH}$ values according to days of storage, although no reduction in the population of Clostridium have been observed, values remained constant during storage, it may be concluded that inhibition in pathogenic microorganisms growth was favored. The control of development of bacterias of the genus Clostridium depends mainly on $\mathrm{pH}$ reduction and increase of osmotic pressure (greater DM content). According to MCDONALD et al. (1991), the reduction of $\mathrm{pH}$ values can reduce the growth of these microorganisms.

There was significance of the storage period only regarding the fungus and yeast population, which increased in 17 days of storage, with later reduction (Figure 2). According to WOOLFORD (1994), silages that have yeast counts above 5.0log $\mathrm{g}^{-1}$ of silage are more susceptible to deterioration, and they may cause changes in the nutritional value of the material, due to degradation of the nutrients and production of mycotoxins, which may harm the livestock. After three days of storage, the fungus and yeast population count remained above $5.21 \mathrm{log} \mathrm{g}^{-1}$ of the residue. This high number of fungi and yeasts, even in an evaluation period considered to be short, may be a result of the presence of oxygen and the high moisture content of the material.

According to MUCK et al. (1996) some species of filamentous fungi, such as those of the genera Aspergillus, Fusarium and Penicillium, may be developed in silages in the presence of air. 


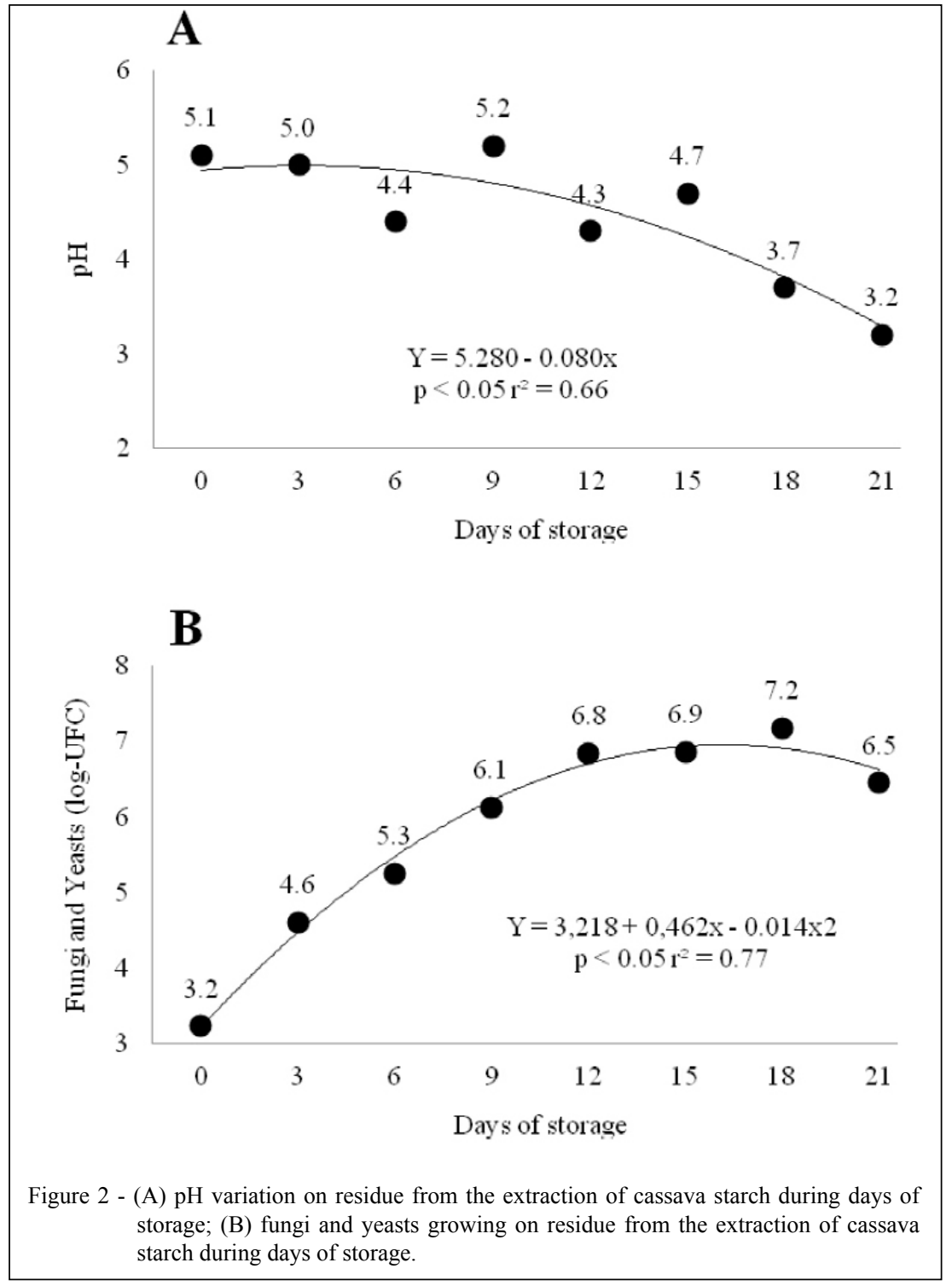

Most fungi are strictly aerobic organisms, capable of developing in organic matter in general, and are able to grow in diverse substrates, being more tolerant to changes in the medium since they are less sensitive to high osmotic pressures, and are capable of tolerating high concentrations of acids, bearing $\mathrm{pH}$ variations from 2 to 9 .

Fungi and yeasts are the main microorganisms responsible for degradation of the residue under aerobic conditions, and may cause

Table 2 - Changes in the $\mathrm{pH}$, temperature values and development of microorganisms $\left(\log _{10} \mathrm{CFU} \mathrm{g} \mathrm{g}^{-1}\right)$ of the residue from the extraction of cassava starch over the 21 days of storage.

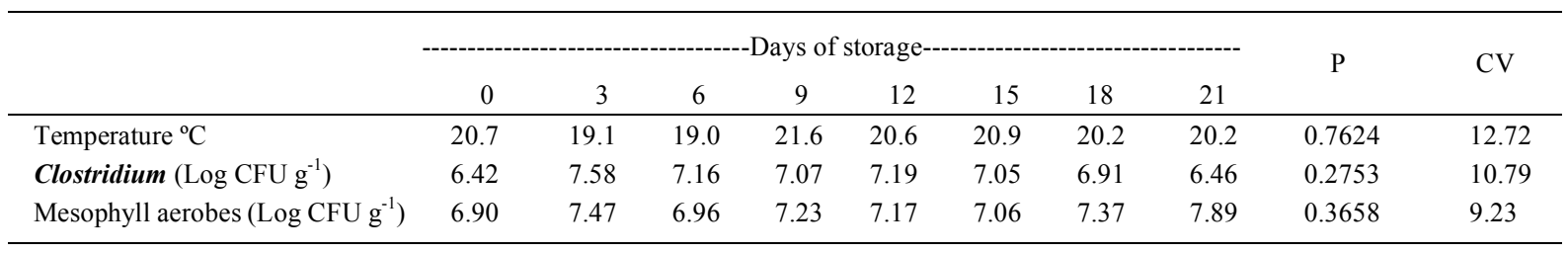

$\mathrm{P}$ : level of significance; $\mathrm{NS}=\mathrm{P}>0.05 ; \mathrm{CV}(\%)$ : coefficient of variation. 
large losses at the surface regions of silos; moreover, they may make use of sugars and lactic acid, causing losses of dry matter and reducing the quality of the fermentation process, affecting preservation of the ensiled material (ARCURI et al., 2003).

Of the mycotoxins researched, zearalenone was the most frequently found, occurring in $100 \%$ of the samples analyzed, and aflatoxin was detected in $35 \%$ of samples, but significant difference was not detected (Table 3). The levels that were detected are below the limits suggested by Brazilian legislation for corn and wheat grain destined human consumption (MINISTRY OF HEALTH, 2011), and below limits of $250 \mu \mathrm{g} \mathrm{kg}^{-1}$ of zearalenone, recommended for feed rations and concentrates for ruminants by Freire et al., (2007).

However, the levels of aflatoxin detected were found to be above that recommended by the Ministry of Agriculture, Livestock and Food (Ministério da Agricultura, Pecuária e Abastecimento) - MAPA, which recommends the limit of $50 \mu \mathrm{g} \mathrm{kg}^{-1}$ of aflatoxins $(\mathrm{B} 1+\mathrm{B} 2+\mathrm{G} 1+\mathrm{G} 2)$ for feeds intended for livestock consumption (direct ingestion or raw material for feed rations).

According to SANTIN (2005), mycotoxins are produced mainly in stress conditions undergone by fungi, such as changes in temperature, moisture or aeration, and in the presence of aggressive agents. Many studies are being done for the purpose of identifying the contamination of feeds by mycotoxins and the effects on livestock. That way, legislation seeks to establish limits that are tolerated by livestock, without causing harm to their health and productivity.

\section{CONCLUSION}

Storage of residue from the extraction of starch from cassava in the concrete floor with plastic sheet cover is not an efficient process, since resulted in the development of fungi and mycotoxins, damaging the quality of the material. There is a need for adoption of conservation technologies, such as drying or ensiling the material.

Table 3 - Incidence of mycotoxins in samples from residue from the extraction of cassava starch over 21 days of storage in each experimental period.

\begin{tabular}{lcccl} 
& \multicolumn{5}{l}{ Mycotoxin $\left(\mu \mathrm{g} \mathrm{kg}^{-1}\right)$} & \multicolumn{2}{c}{---Days of storage---- } & $\mathrm{P}$ & \\
& 0 & 21 & & \\
\hline Aflatoxin & 55.0 & 159.0 & 0.0969 & 185.349 \\
Zearalenone & 44.0 & 58.5 & 0.4863 & 20.356 \\
\hline
\end{tabular}

\section{REFERENCES}

ABRAHÃO, J.J.S. et al. Digestibilidade de dietas contendo resíduo úmido de mandioca em substituição ao milho para tourinhos em terminação. RevistaBrasileira de Zootecnia, v.35, n.4, p.512518, 2006. Available from: <http://dx.doi.org/10.1590/S151635982006000500026>. Accessed: Oct. 22, 2012. Doi: 10.1590/ S1516-35982006000500026.

ASSOCIATION OF ANALYTICAL CHEMISTS (AOAC) AGRICULTURAL CHEMISTS. Official methods of analysis. 15.ed. Arlington, Virginia, D.C.: 1990, 1117p.

ARCURI, P.B. et al. Microrganismos indesejáveis em forragens conservadas: efeito sobre o metabolismo de ruminantes. In: REIS, R.A. et al. (Ed.). VOLUMOSOS NA PRODUÇÃO DE RUMINANTES: VALOR ALIMENTÍCIO DE FORRAGENS, 2003, Jaboticabal, SP. Anais... Jaboticabal: FUNEP, 2003. p.51-70.

CEREDA, M.P. Caracterização dos subprodutos da industrialização da mandioca. In: Manejo, uso e tratamento de subprodutos da industrialização da mandioca. São Paulo: Fundação CARGILL, 2000. p.13-37.

CHERNEY, J.H.; CHERNEY, D.J.R. Assessing silage quality. In: BUXTON, D.R.; MUCK. R.E.; HARRISON, J.H. (Eds.). Silage science and technology. Madison: American Society of Agronomy, Crop Science Society of America, Soil Science of America 2003. p.141-198.

FERNANDES, T. Utilização de resíduo da extração do amido da mandioca seco na alimentação de ruminantes. 2014. 68f. Dissertação (Mestrado em Zootecnia) - Programa de Pós - graduação em Zootecnia, Universidade Estadual do Oeste do Paraná, PR.

FREIRE, F.C.O. et al. Micotoxinas: importância na alimentação e na saúde humana e animal. Fortaleza: Empresa Brasileira de Pesquisa Agropecuária. Embrapa Agroindústria Tropical, 2007. (Documento 110), Available from: <http://www.cnpat.embrapa.br/ cnpat/cd/jss/acervo/Dc_110.pdf.>. Accessed: Nov. 14, 2012.

GONÇALVES, J.A.G. et al. Composição químico-bromatológica e perfil de fermentação da silagem de resíduo úmido de fécula de mandioca. Bioscience Journal, v.30, n.2, p.502-511, 2014. Available from: <http://www.seer.ufu.br/index.php/ biosciencejournal>. Accessed: Mar. 14, 2014.

JAY, J. Microbiologia de alimentos. 6.ed. Porto Alegre: Artmed, 2005. 712p

JOBIM, C.C. et al. Avanços metodológicos na avaliação da qualidade da forragem conservada. Revista Brasileira de Zootecnia, v.36, supl. Esp., p.101-119, 2007. Available from: $<$ http://dx.doi.org/10.1590/S1516-35982007001000013>. Accessed: Mar. 13, 2014. doi: 10.1590/S1516-35982007001000013

LIMA, L.P. et al. Bagaço de mandioca (Manihot esculenta, Crantz) na dieta de vacas leiteiras: consumo de nutrientes. Arquivo Brasileiro de Medicina Veterinária e Zootecnia, v.60, n.4, p.1004-1010, 2008. Available from: <http://dx.doi.org/10.1590/ S0102-09352008000400032>. Accessed: Oct. 13, 2012. doi: $10.1590 / \mathrm{S} 0102-09352008000400032$

MCDONALD, P. et al. The biochemistry of silage. 2.ed. Marlow: Chalcombe Publications, 1991. 340p. 
MINISTÉRIO DA SAÚDE. Resolução n 7 , de 18 de Fevereiro de 2011 - Dispõe sobre limites máximos tolerados (LMT) para micotoxinas em alimentos. Diário Oficial da União, n.37, 22-22011, Seção 1, p.72.

MUCK, R.E. Inoculation of silage and its effects on silage quality. In: INFORMATIONAL CONFERENCE WITH DAIRYAND FORAGE INDUSTRIES, 1996, Madison. Proceedings... Madison: USDFRC, 1996. p.43-51.

RAMALHO, R.P. et al. Substituição do milho pela raspa de mandioca em dietas para vacas primíparas em lactação. Revista Brasileira de Zootecnia, v.35, n.3, p.1221-1227, 2006. Available from: <http://dx.doi.org/10.1590/S1516-35982006000400037>. Accessed: Nov. 09, 2012. doi: 10.1590/S1516-35982006000400037

SANTIN, E. Mould growth and mycotoxin production. In: DIAZ, D.E. The mycotoxin blue book. Nottingham: Nottingham University, 2005. p.225-234

SERVIÇO BRASILEIRO DE APOIO ÀS MICRO E PEQUENAS EMPRESAS (SEBRAE). Mandiocultura, farinha e fécula. Brasilia, 2012. 69p. (Série de Estudos Mercadológicos).
SILVA, N. et al. Manual de métodos de análise microbiológica de alimentos. São Paulo: Varela, 1997. 295p.

SOUZA, L.C. et al. Development of microorganisms during storage of wet brewery waste under aerobic and anaerobic conditions. Revista Brasileira de Zootecnia, v.41, n.1, p.188193, 2012. Available from: <http://dx.doi.org/10.1590/S151635982012000100027>. Accessed: Nov. 09, 2012. doi: 10.1590/ S1516-35982012000100027.

VAN SOEST, P.J. Nutritional ecology of the ruminant. Ithaca: Constock Publishing Associates, 1994. 476p.

VAN SOEST, P.J. et al. Symposium: carbohydrate methodology, metabolism, and nutritional implications in dairy cattle. Journal of Dairy Science, v.74, n.10, p.3583-3597, 1991.

WOOLFORD, M.K. The silage fermentation. New York: Marcel Dekker, 1994. $14 \mathrm{v}$.

ZAMBOM, M.A. et al. Uso de co-produtos na alimentação de bovinos leiteiros. In: SANTOS, G.T. et al. (Org.). V Sul Leite: Simpósio sobre Sustentabilidade da Pecuaria Leiteira na Região Sul do Brasil. Maringa: Sthampa, 2012. V.1, p.201-233. 